\title{
Pollen and plant macrofossils at Lac de Fully (2135 m a.s.1.): Holocene forest dynamics on a highland plateau in the Valais, Switzerland
}

\author{
Walter Finsinger ${ }^{1 *}$ and Willy Tinner ${ }^{2,3}$
}

\author{
( ${ }^{1}$ Palaeoecology, Institute of Environmental Biology, Utrecht University, Laboratory of Palaeobotany \\ and Palynology, Budapestlaan 4, NL-3584 CD Utrecht, The Netherlands; ${ }^{2}$ Paleoecology and Vegetation \\ Dynamics, Institute of Terrestrial Ecosystems, Department of Environmental Sciences, ETH Zurich, \\ CH-8092 Zurich, Switzerland; ${ }^{3}$ Section of Palaeoecology, Institute of Plant Sciences, University of \\ Bern, Altenbergrain 21, CH-3013 Bern, Switzerland)
}

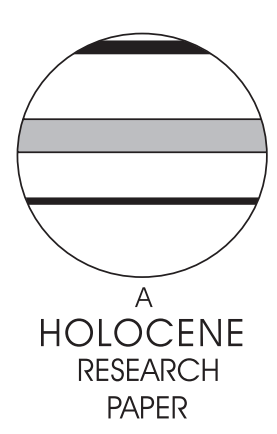

\section{Introduction}

The transition between forest and alpine meadows (or treeless tundra) is one of the major and fascinating worldwide ecotonal boundaries, the treeline ecotone (Körner and Paulsen, 2004). The treeline ecotone spans the timberline (ie, the uppermost limit of closed forest) and the tree species limit or krummholz limit (ie, the uppermost limit of isolated and small individuals). Near the treeline (ie, the uppermost limit of isolated groups of tall trees $>2-5 \mathrm{~m}$ in height) the growth of plants is limited by climatic conditions (such as the length of the growing season; Körner and Paulsen, 2004). Changes in elevation of the treeline during the past century (eg, Kullman, 2002; Parmesan, 2006

*Author for correspondence (e-mail: w.finsinger@uu.nl) and references therein) unambiguously show how fast plants may respond to climatic change (eg, Menzel and Fabian, 1999) in these harsh environments. This sensitivity has been used to reconstruct Holocene-climatic variability based on changes in treeline elevation inferred from pollen and plant macrofossils in lake sediments (eg, Wick and Tinner, 1997; Haas et al., 1998; Kaltenrieder et al., 2005), from phytolith assemblages in palaeosoils (eg, Carnelli et al., 2004), and from megafossils and dendrochronologically dated subfossil logs (eg, Carrara et al., 1991; Kullman, 1995; Nicolussi et al., 2005). Little is known, however, as to the changes in species composition of timberline forests in response to climatic change, although the present distribution of trees in the Alps (Landolt, 1992) and modelling results (Heiri et al., 2006) indicate the sensitivity of timberline vegetation also to climatic parameters other than growing-season length (eg, amount or seasonal distribution of precipitation). 


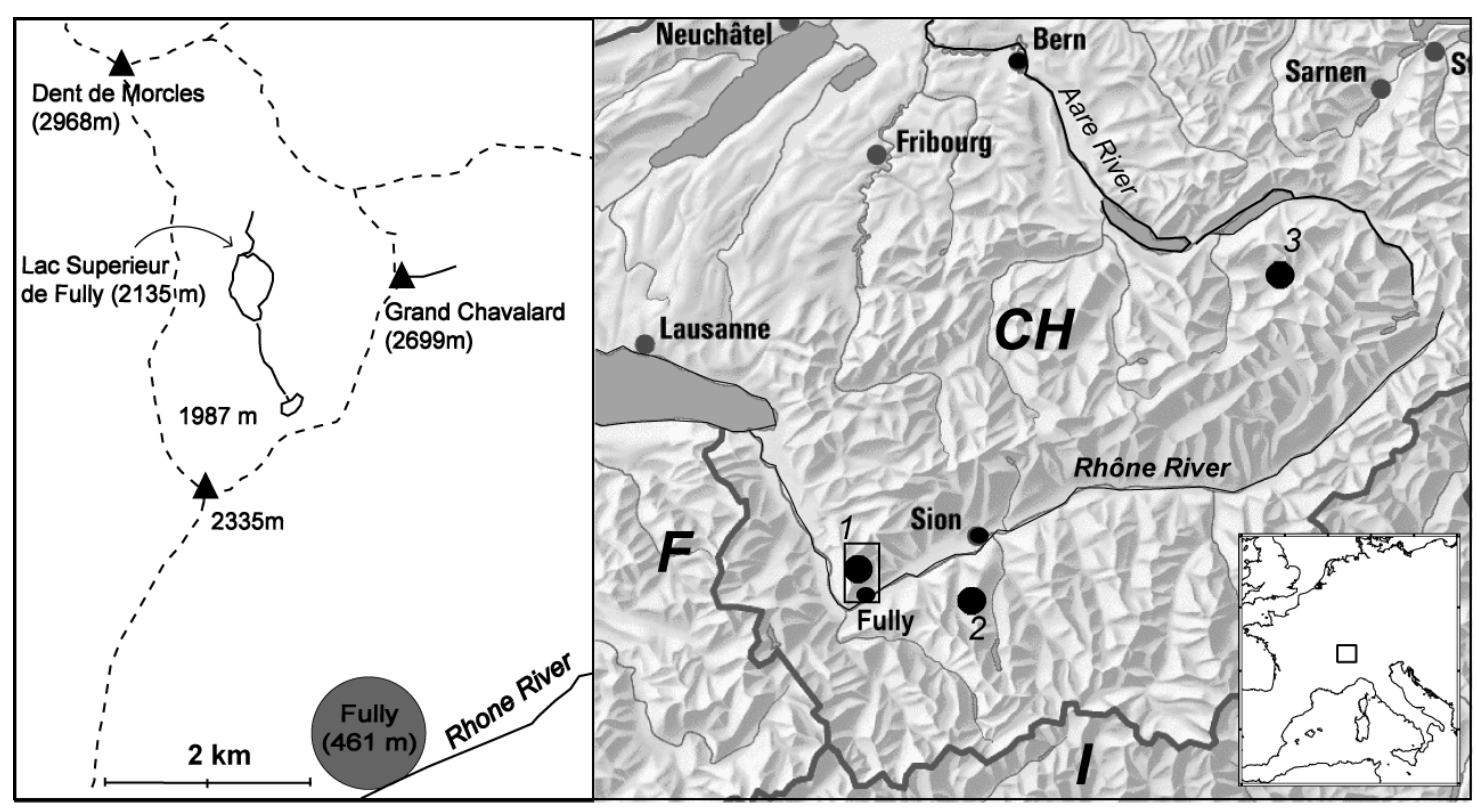

Figure 1 Left: sketch map of the Lac de Fully valley (dotted lines, watersheds; continuous lines, rivers); Right: location of study sites mentioned in the text: 1, Lac de Fully (2135 m a.s.1.); 2, Gouille' Rion (2343 m a.s.l.); 3, Hinterburgsee (1515 m a.s.l.)

Here we report on pollen and plant-macrofossil records to reconstruct the vegetation dynamics at Lac Supérieur de Fully, which is located at $2135 \mathrm{~m}$ a.s.l. on a south-facing highland plateau in the Central Alps (Figure 1). Although the lake is located below the modern treeline (which might correspond to the elevation of the potential (natural) timberline at c. $2200 \mathrm{~m}$ a.s.l.; Landolt, 1992) and near the modern regional timberline (c. 2000-2100 m a.s.1.), trees are absent above $1950 \mathrm{~m}$ a.s.l. in the lake catchment. We were therefore particularly interested to know if the timberline ever reached the catchment during the warmest phase of the Holocene and how the species composition changed in response to Holocene climatic changes.

\section{Site description}

The Valais, ie, the Swiss part of the Rhône Valley, is an inneralpine valley positioned SE-NW (Figure 1) and characterized by a dry climate mainly caused by inner-valley shielding (average annual rainfall of about $600 \mathrm{~mm}$ at low elevation $(600 \mathrm{~m}$ a.s.1.) and about $1000 \mathrm{~mm}$ at $2300 \mathrm{~m}$ a.s.l.; Heiri et al., 2006). Although the amount of rainfall on the south- and north-facing slopes is similar, vapour-pressure deficit is higher on the south-facing slope because of more intense sunlight. This causes more evaporation and drought stress to plants living there than to plants on the north-facing slope (Zweifel et al., 2006). The different microclimate is reflected in the present vegetation: Quercus pubescens, Pinus sylvestris and Juniperus sabina are abundant on the south-facing slope, while on the north-facing slope the drought-sensitive Abies alba forms major stands and thermophilous and drought-adapted $Q$. pubescens is lacking (Steiger, 1995). The natural treeline in the Valais occurs at about 2200-2400 $\mathrm{m}$ a.s.l., although only a few forests can be found above $2200 \mathrm{~m}$ a.s.l. today (Tinner and Theurillat, 2003; Heiri et al., 2006).

Lac Supérieur de Fully has an area of c. 25 ha and is located at the bottom of a former glacier cirque in a local highland of $c .10$ $\mathrm{km}^{2}$ area. The site is bordered by mountain chains reaching 2300 to $3000 \mathrm{~m}$ a.s.l. towards west, east and north (Figure 1). The bedrock geology at the site is dominated by sedimentary deposits
(Carboniferous, Triassic, Jurassic and Cretaceous). The lake has a minor inlet on the north and an outlet on the south. An artificial dam c. $100 \mathrm{~m}$ long was built AD 1912-1914 to increase the size of the lake. Climatic conditions at these elevations are harsh. Annual mean temperature at $2100 \mathrm{~m}$ is $c .2^{\circ} \mathrm{C}$, July mean temperature $c$. $9^{\circ} \mathrm{C}$, and annual precipitation $c .1000 \mathrm{~mm}$ (linear interpolations and extrapolations from stations in the Valais region).

\section{Materials and methods}

A continuous section $268 \mathrm{~cm}$ long was taken in late summer 2003 from an open pit at Lac Supérieur de Fully (GPS: 573'372; 113' 983; $2135 \mathrm{~m}$ a.s.1.). Lake-level was low at that time because the dam had been kept open during the previous year. The section was collected in overlapping segments $50 \mathrm{~cm}$ long and stored at $+4^{\circ} \mathrm{C}$ room temperature in the Institute of Plant Sciences (University of Bern). The sediment was subsampled for pollen and plant-macrofossil analyses ( $1 \mathrm{~cm}$ thick slices) avoiding the sand layers (Table 1). For pollen analysis, 64 samples were prepared, but only 62 were analysed because pollen in the clayey sediment at the base of the sequence (ie, $266 \mathrm{~cm}$ and $257 \mathrm{~cm}$ depth) was virtually absent. Lycopodium spores were first added to $1 \mathrm{~cm}^{3}$ of sediment in order to calculate pollen concentrations, following Stockmarr (1971). Samples were treated physically and chemically, following standard procedures (Moore et al., 1991). The residue was mounted in glycerine on slides and analysed

Table 1 Simplified sediment description of the studied section at Lac Supérieur de Fully

\begin{tabular}{ll}
\hline Depth $(\mathrm{cm})$ & Sediment description \\
\hline $0-18$ & Sand \\
$18-20$ & Sandy gyttia \\
$20-26$ & Sand layer (coarsening upward) \\
$26-30.5$ & Sandy gyttia \\
$30.5-237$ & Stratified sandy gyttia with distinct sand layers \\
$237-248$ & Stratified gyttia \\
$248-270$ & Stratified sandy silt with distinct sand layers \\
\hline
\end{tabular}


Table 2 Radiocarbon dates and calibrated ${ }^{14} \mathrm{C}$-ages used to derive the depth-age relationship of the Lac de Fully sediment sequence

\begin{tabular}{|c|c|c|c|c|c|c|}
\hline Lab. code & $\begin{array}{l}\text { Depth } \\
(\mathrm{cm})\end{array}$ & $\begin{array}{l}\text { Macrofossils selected } \\
\text { for dating }\end{array}$ & $\begin{array}{l}\delta^{13} \mathrm{C} \\
(\% \text { PDB) }\end{array}$ & $\begin{array}{l}{ }^{14} \mathrm{C} \text { age } \\
( \pm 1 \sigma)\end{array}$ & $\begin{array}{c}\text { Calibrated } \\
{ }^{14} \mathrm{C} \text { age (cal. BP) }\end{array}$ & $\begin{array}{l}2 \sigma \text { range } \\
(\text { cal. yr BP) }\end{array}$ \\
\hline $\mathrm{P}-\mathrm{I}^{\mathrm{b}}$ & 44 & 1 & - & $1500 \pm 100$ & 1400 & $1690-1190$ \\
\hline Poz-10657c & 43 & indet. wood (-bark) & -21.2 & $5450 \pm 40$ & 6247 & $6310-6186$ \\
\hline Dendro-90265 & 100 & Larix & - & - & 4693 & $4703-4683$ \\
\hline ETH-29190 & 124 & Larix & -24.0 & $4600 \pm 55$ & 5316 & $5470-5054$ \\
\hline Poz-10658 & 138 & Larix N S, indet. BS & -30.7 & $5320 \pm 40$ & 6097 & $6266-5956$ \\
\hline \multirow[t]{2}{*}{ Poz-10660 } & 171 & Larix N S, Betula BS & & & & \\
\hline & & $\mathrm{F}$, indet. bark & -29.1 & $6640 \pm 40$ & 7525 & $7581-7441$ \\
\hline Poz-10661 & 191 & J. nana $\mathrm{N}$, Larix $\mathrm{N}$ & -32.4 & $7420 \pm 40$ & 8258 & 8343-8176 \\
\hline Poz-10662 & 241 & $\begin{array}{l}\text { indet. wood (+ bark), } \\
\text { Betula } \mathrm{F}\end{array}$ & -28.2 & $9390 \pm 50$ & 10622 & $10743-10550$ \\
\hline
\end{tabular}

a Abbreviations: N, needle; S, seed; BS, budscale; F, fruit; L, leaf fragment; (+/- bark), with/without bark.

${ }^{b} \mathrm{P}-\mathrm{I}$, pollen-inferred age based on the correlation of the Lac de Fully pollen record with the pollen stratigraphy in nearby Gouillé Rion (Tinner et al., 1996). ${ }^{\mathrm{c}}$ Rejected ${ }^{14} \mathrm{C}$ date.

${ }^{\mathrm{d}}$ Dendrochronologically inferred age (see text for details).

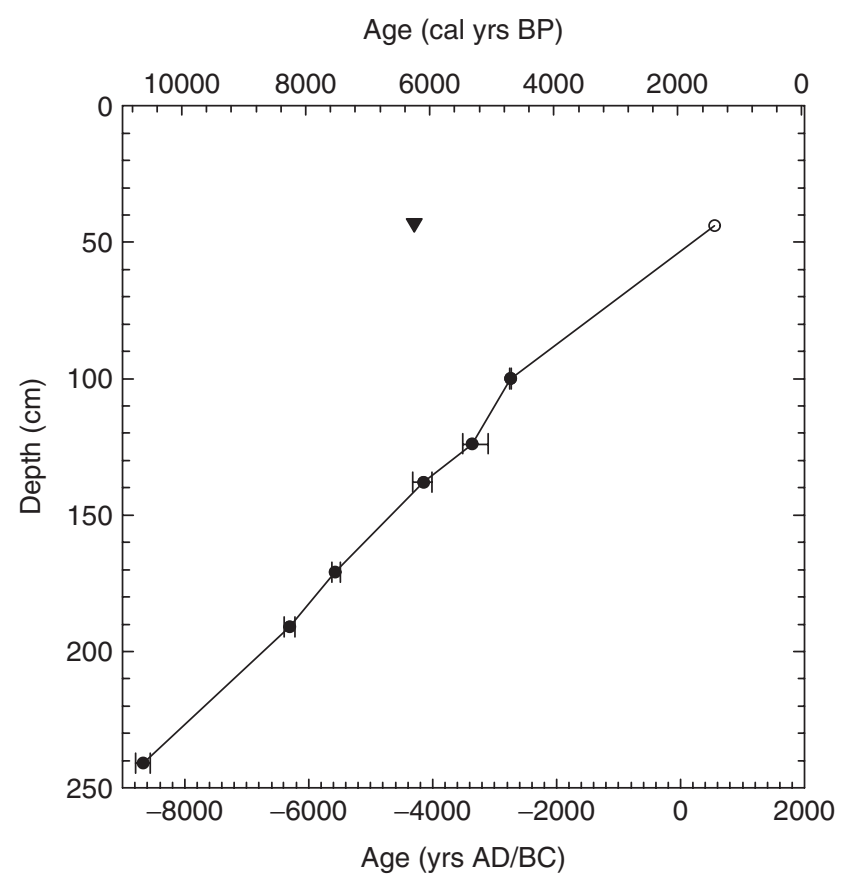

Figure 2 Depth-age relationship of the Lac de Fully sediment sequence. The error bars indicate calibrated $2 \sigma$ ranges for the calibrated ${ }^{14} \mathrm{C}$ dates. Full circle, calibrated ${ }^{14} \mathrm{C}$ date; empty circle, polleninferred age; triangle, rejected ${ }^{14} \mathrm{C}$ date (see text and Table 2 for details)

at $\times 400$ magnification. At least 300 pollen grains were counted for each pollen sample. The pollen key of Moore et al. (1991) and the photographic pollen atlas of Reille $(1992,1995)$ were used. Pollen percentages are referred to the sum of terrestrial pollen, which includes trees, shrubs, herbs and terrestrial ferns. Microcharcoal particles were counted on pollen slides following Tinner and $\mathrm{Hu}$ (2003) and Finsinger and Tinner (2005). Conifer stomata were identified following Trautmann (1953).

For plant-macrofossil analysis, 84 sediment samples were taken between $246 \mathrm{~cm}$ and $29 \mathrm{~cm}$ depth. Sediment volume was measured by water displacement before samples were soaked in pyrophosphate $5 \%$ for $1-2 \mathrm{~h}$ and washed through a $200 \mu \mathrm{m}$ sieve. The residue was collected and stored in distilled water at $-18^{\circ} \mathrm{C}$ to avoid contamination with recent carbon (Wohlfahrt et al., 1998).
Plant macrofossils were analysed with a binocular 10-50 $\times$ magnifications. Plant remains of 13 taxa were identified.

Plant macrofossils collected from five samples (Table 2) were washed twice in distilled water, dried overnight at $60^{\circ} \mathrm{C}$, and analysed under the microscope for absence of recent carbon sources (eg, wool, cotton, fibres) before they were sent to the Poznan Radiocarbon Laboratory. In addition to these macrofossils, we used one dendrochronologically inferred age (No. 90265.0, M. Schmidhalter, personal communication, 2004) and one ${ }^{14} \mathrm{C}$-age (No. 90266.0, M. Schmidhalter, personal communication, 2004), which estimate the age of death of two tree trunks present in the stratigraphy. All ${ }^{14} \mathrm{C}$ ages were calibrated to calendar ages using the Calib5 program and selecting the IntCal04 data set (Reimer et al., 2004). The depth-age relationship was established with a linear interpolation of median probability ages (Figure 2). One ${ }^{14} \mathrm{C}$ age (at $43 \mathrm{~cm}$ depth) was rejected from the model because it appeared to be too old and was replaced with a pollen-inferred age estimate based on the first appearance and increase of Castanea pollen (Figure 3), which is dated to $c .1500 \mathrm{BP}$ in radiocarbon-dated pollen records of that region (Tinner et al., 1996).

The pollen data were zoned numerically with the optimal-sum-ofsquares partitioning (Birks and Gordon, 1985). The application of a broken stick model (Bennett, 1996) showed four statistically significant pollen assemblage zones (PAZ). The plant-macrofossil data were zoned visually into five macrofossil assemblage zones (MAZ).

\section{Results and interpretation}

\section{Pollen stratigraphy and vegetation history}

The lowest pollen assemblage zone (FUY-1; 11 000-7400 cal. BP; Figure 3) is dominated by P. sylvestris, P. cembra and Corylus pollen. High values of Ulmus pollen may suggest that, together with Corylus, these trees were fairly abundant on the mountain slopes at lower elevation. Pinus, Larix and Juniperus stomata attest to the presence of these trees and shrub taxa near the lake after $c .9000 \mathrm{cal}$. BP. Alnus viridis pollen was present in low amounts, suggesting the local (but rare) presence of the shrub in the area. Based on the pollen assemblages the base of this zone is attributed to the early Holocene.

Zone FUY-2 (c. 7400-4700 cal. BP) is characterized by high percentages of Abies and P. cembra, which were present in the lake catchment as suggested by the continuous presence of conifer stomata in the pollen slides. Ulmus percentages decrease during 


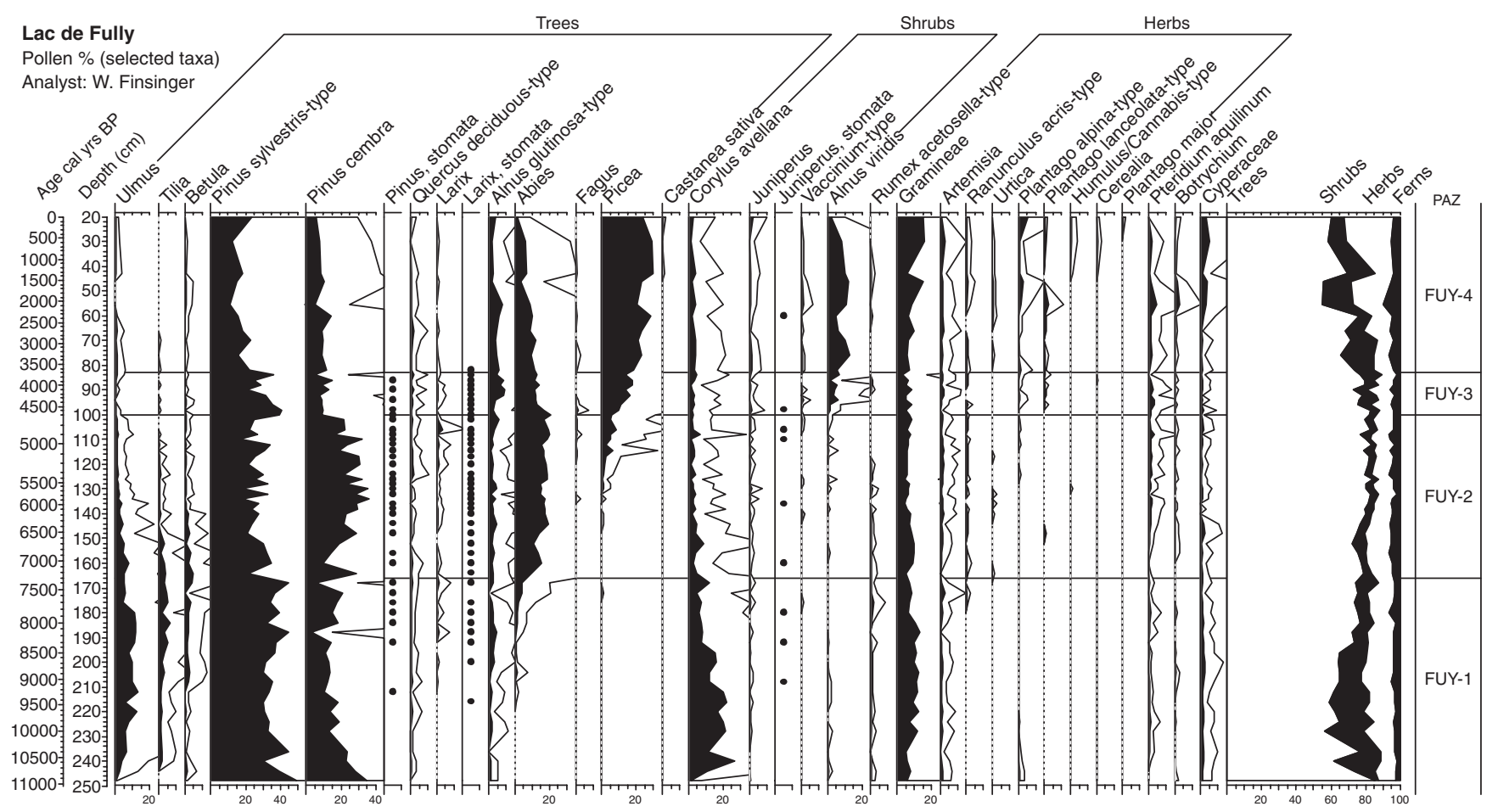

Figure 3 Pollen diagram for Lac de Fully. Only a selection of taxa are shown (the complete records are available from the authors). Zones refer to pollen assemblage zones (PAZ)

this zone, possibly indicating a continued forest reduction at lower altitudes. The presence of Plantago lanceolata and Plantago alpina pollen, two cultural indicators for agricultural activities (cf. Behre, 1981), may attest to human activities in the valley and possibly near the lake. Discontinuous presence and low percentages of Urtica pollen since the onset of this zone might be linked to grazing (cf. Behre, 1981) and nitrogen-rich soils on the mountain slopes, although, just as with Plantago alpina, the plant occurs also naturally in the area. In zone FUY-3 (c. 4700-3700 cal. BP) pollen values of Picea and $A$. viridis increased, while Abies and $P$. cembra percentages decreased. The complete collapse of the conifer forest in the lake catchment, however, can be ruled out because of the presence of conifer stomata (Larix and Pinus) in this zone. Human activities in the valley increased, as inferred from higher percentages of cultural indicators (eg, P. lanceolata, P. alpina). Zone FUY-4 (3700 cal. BP-present) is characterized by high percentages of $A$. viridis and Picea, lower percentages of Larix and Pinus, and the absence of conifer stomata.

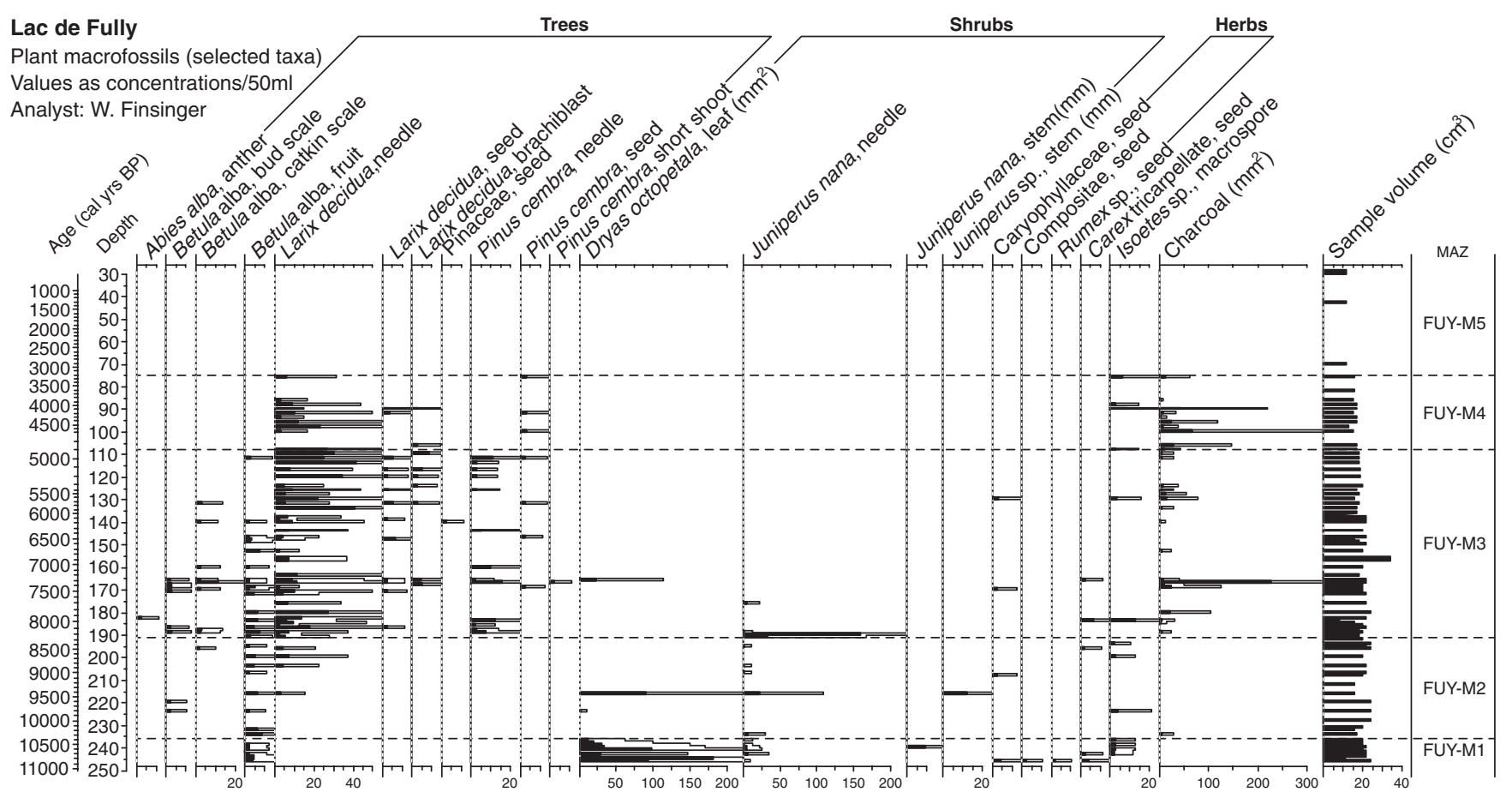

Figure 4 Macrofossil diagram for Lac de Fully. Only a selection of taxa are shown (the complete records are available from the authors). Zones refer to macrofossil assemblage zones (MAZ). Results are given as plant-macrofossil concentrations in $50 \mathrm{~cm}^{3}$ 


\section{Macrofossil stratigraphy and local vegetation history}

The first macrofossil zone (FUY-M1; 11 000-10 $300 \mathrm{cal}$. BP) is initially dominated by alpine dwarfshrubs and shrubs (Dryas octopetala and Juniperus nana) and by tree birches (Betula ('alba')) (Figure 4), suggesting the presence of light-demanding trees, shrubs and heaths around the lake. In the second zone (FUYM2; 10300-8300 cal. BP), Larix decidua needles indicate stands of this coniferous tree near the lake. Macroscopic charcoal fragments are absent in all samples. After 8300 cal. BP (onset of FUYM3) the macrofossil assemblage is dominated by remains of coniferous trees (P. cembra, Larix) and Betula ('alba'), indicating the establishment of rather closed forests around the lake. At the onset of this zone high concentrations of J. nana needles occur, suggesting that the establishment of forests was preceded by the formation of rather dense J. nana heaths around the lake. Macroscopic charcoal fragments are present in many samples, and three of them were identified as Larix/Picea $(166 \mathrm{~cm}$ and $180 \mathrm{~cm})$ and $P$. cembra $(167 \mathrm{~cm})$, indicating that local forest fires occurred around the lake. Because of the virtual absence of Abies macrofossils, we infer that this species never really played a major role in the forest vegetation at the elevation of Lac de Fully. The only evidence for the presence of Abies near the lake is given by one single anther (identified through its pollen content), which could have been transported by wind. Zone FUY-M4 (4900-3200 cal. BP) is characterized by high concentrations of Larix and charcoal fragments, the absence of Betula remains and only few P. cembra seeds, suggesting that heliophilous Larix stands or forests prevailed around the lake. Plant macrofossils such as leaves, needles and fruits are lacking in the uppermost zone (FUY-M5; < 3200 cal. BP), and the wood fragment at $43 \mathrm{~cm}$ depth (as inferred from the ${ }^{14} \mathrm{C}$ date, Table 2) might be so old because of the longer terrestrial residence time of wood.

\section{Discussion}

In mountain regions pollen spectra at high altitude also contain pollen grains produced by plants growing in vegetation belts at lower elevations and thus do not reflect the local vegetation accurately. Therefore, inferences on changes in vegetation composition and treeline elevation are substantially improved by considering plant macrofossils (Birks and Birks, 2000; Tinner and Theurillat, 2003). In the Lac Supérieur de Fully record, however, pollen, stomata and plant macrofossils of Betula, Larix and P. cembra show similar changes in their abundances (Figure 5). We may therefore infer that changes in pollen percentages of these timberline species were not primarily influenced by changes in pollen productivity (Autio and Hicks, 2004) but by changes in population densities of the timberline forests, which is in agreement with recent modelling results (Heiri et al., 2006).

\section{Vegetation response to long-term climate change}

The general trend observed at many high-elevation sites (> 1600-1800 $\mathrm{m}$ a.s.1.) in the Alps involves afforestation at the beginning of the Holocene and a subsequent decline of the timberline by several $100 \mathrm{~m}$ at c. $5000 \mathrm{cal}$. BP (Burga and Perret, 1998). It resulted mainly from climatic changes that were probably coupled to changes in summer and winter insolation (Tinner and Kaltenrieder, 2005) as well as from human disruption of forests, which led to an artificial lowering of the timberline after $c .5000$ cal. BP (Tinner and Theurillat, 2003). This long-term trend is also reflected in the pollen and macrofossil record from Lac de Fully (Figures 3, 4 and 5): an open alpine vegetation dominated by shrubs (Dryas octopetala and J. nana) was followed by an open

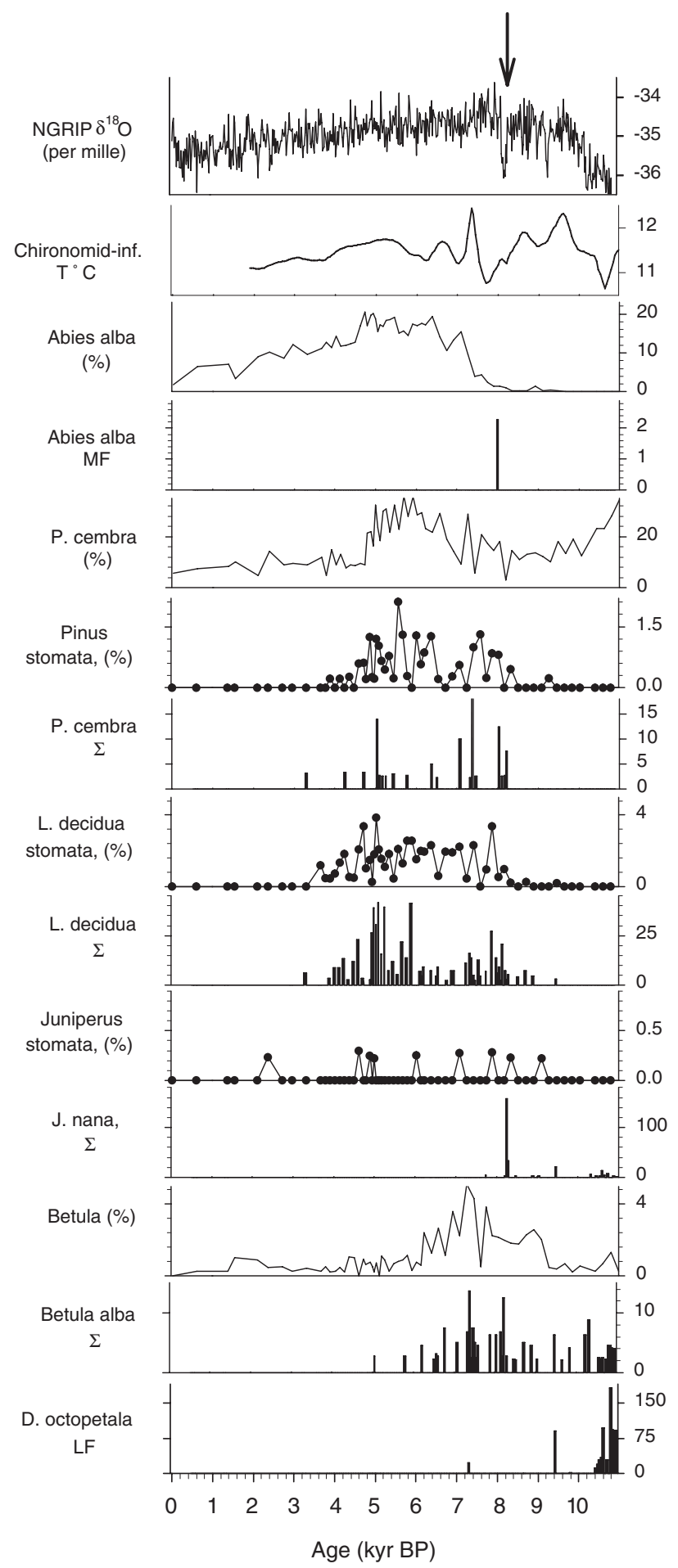

Figure 5 Comparison between early and middle Holocene forest dynamics at Lac de Fully, a proxy record for summer air temperature in the Alps (Heiri et al., 2004), and $\delta^{18} \mathrm{O}$ in Greenland (Rasmussen et al., 2006). Plant macrofossils (histograms), pollen (line), stomata (line with solid circles) of selected taxa. Arrow (top) indicates the $8.2 \mathrm{ka}$ event in the ice-core record

treeline condition with shrubs and sparse trees (Betula and Larix) since $9500 \mathrm{cal}$. BP. Then, at c. $8300 \mathrm{cal}$. BP, P. cembra and Larix expanded in the catchment, indicating the maximum expansion of timberline, which dominated the local vegetation and the highland plateau until c. $3500 \mathrm{cal}$. BP.

\section{Vegetation response to the abrupt climate change at 8.2 ka}

Superimposed on the long-term millennial climatic trend, which primarily resulted from variations in the Earth's orbit, centennial- 
scale abrupt climatic changes occurred. Among these abrupt climate changes, the ' 8.2 ka event' (Wick and Tinner, 1997; Alley et al., 1997; Rohling and Pälike, 2005) stands out as being one of the most pronounced and probably therefore most studied abrupt climatic changes that occurred during the Holocene. The existence of a unique event at c. $8200 \mathrm{cal}$. BP around the North Atlantic is no longer in question, but there remain uncertainties about how widespread the anomalies were and how well the length, duration and character of the event can be characterized (Alley and Àgustdòttir, 2005; Rohling and Pälike, 2005; Nesje et al., 2006). The currently favoured hypothesis is that these anomalies were related to a transient change in the North Atlantic overturning circulation (Came et al., 2007), possibly triggered by the final drainage of Lake Agassiz (eg, Nesje et al., 2004). The isotope data suggest a climate cooling of $\sim 1.7^{\circ} \mathrm{C}$ in mean-annual air temperature in Central Europe (von Grafenstein et al., 1998). In the Alps a chironomid-inferred July air-temperature decrease of $\sim 1^{\circ} \mathrm{C}$ at high elevation shows a close temporal agreement with the 8.2 ka event in the Greenland ice-core records, but suggests that the cooling in the Alps may have been protracted by several centuries (Heiri et al., 2003, 2004; Figure 5). A similar feature is indicated also in a speleothem $\delta^{18} \mathrm{O}$ record of the Spannagel Cave (Vollweiler et al., 2006), where the greatest positive $\delta^{18} \mathrm{O}$ anomaly (possibly indicating colder temperatures) occurred after $8000 \mathrm{cal}$. BP and was followed by a rapid climate warming.

The abrupt climate change at $8200 \mathrm{cal}$. BP had important effects in the shaping of vegetation in Central Europe during the Holocene (Tinner and Lotter, 2001), and it caused an unambiguous lowering of the timberline in the Central Alps (Wick and Tinner, 1997; Haas et al., 1998; Tinner and Kaltenrieder, 2005). On the basis of the macrofossil record, it seems likely that at Lac de Fully the shortterm increase of J. nana and collapse of the open Larix forest at c. 8200 cal. BP may indicate the response of local vegetation to the abrupt climate change at $8.2 \mathrm{ka}$ that was very soon followed by the expansion of P. cembra and Larix near the site. A similar pattern has been observed at Gouillé Rion (2343 m a.s.1.), where the collapse of Larix occurred at c. 8400-8300 cal. BP (Tinner and Kaltenrieder, 2005). The subsequent expansion of $P$. cembra that led to the dominance of the species at Gouillé Rion took place at c. 8300-8200 cal. BP (Tinner and Kaltenrieder, 2005).

In contrast to other records in the Valais, early Holocene afforestation at Lac de Fully was delayed by several millennia: Larix remains are absent until 9500 cal. BP and P. cembra remains are absent until 8300 cal. BP, while at Gouillé Rion (2343 m a.s.1.) alpine grasslands were afforested by Larix and J. nana c. 11000 cal. BP and P. cembra expanded at c. $10000 \mathrm{cal}$. BP (Tinner and Kaltenrieder, 2005). Also at lower elevation, macrofossil-inferred afforestation occurred earlier than at Lac de Fully: at Böhnigsee (c. $2100 \mathrm{~m}$ a.s.l.; Markgraf, 1969) and at Simplon (c. $2050 \mathrm{~m}$ a.s.l.; Lang and Tobolski, 1985) timberline rose above these lakes around $11000 \mathrm{cal}$. BP (Tinner and Theurillat, 2003). It is highly unlikely that the difference in the timing of afforestation by P. cembra and Larix depended on the low speed of spread of these species (see discussion in Tinner and Kaltenrieder, 2005) or on climatic gradients producing shorter growing-season lengths at Lac de Fully. Instead, the late expansion of Larix and P. cembra may be explained by the local climatic conditions involving either higher drought stress or shorter growing-season length at Lac de Fully that inhibited their growth in the catchment of the lake. The late appearance of $P$. cembra might be related to its higher drought-stress intolerance than Larix, Dryas and J. nana. Larix sheds its needles in winter, and the two shrubs take advantage of the thermal insulation of snow in late winter, while P. cembra needles are fully exposed to late winter drought stress (Körner, 1999; Tinner and Kaltenrieder, 2005). However, slope contrasts may come into play in low-stature plant cover, when oceanicity, snow pack or general moisture gradients are important, as was shown for subarctic-birch treelines and as can be seen in some very dry parts of central Asia or northern Chile (Körner and Paulsen, 2004). Alternatively, cold-air retention at the bottom of the former glacier cirque might have caused lower soil temperatures, which have a negative influence on tree growth (Körner and Paulsen, 2004; Körner and Hoch, 2006).

Surprisingly, tree-species that had established at the timberline and at lower elevation after $8200 \mathrm{cal}$. BP were significantly different from those that were growing there before. Thus, synchronously with the expansion of $P$. cembra and Larix at the timberline, Abies expanded at lower elevation (Figure 5). We suggest that the expansion of Abies, as inferred from the Lac de Fully pollen record, may indicate that drought stress in the Central Alps was lower after $8200 \mathrm{cal}$. BP. In effect, it is likely that Abies (and Fagus) in Central Europe were at their physiological drought limit during the early Holocene (Tinner and Lotter, 2001), when negative precipitation anomalies occurred $(<-400 \mathrm{~mm}$ annual precipitation in comparison with today; Guiot et al., 1993) and seasonality was enhanced because of higher summer insolation and lower winter insolation (Kutzbach and Webb, 1993). The successful expansion of A. alba and Fagus in the lowlands of Central Europe further suggests that after $8200 \mathrm{cal}$. BP climatic conditions did not return to the early Holocene mode with its frequent (summer) droughts and (spring) frosts, which favoured the abundance of Corylus (Tinner and Lotter, 2001; Finsinger et al., 2006).

Although some proxies of climatic change do not show a significant difference in climatic conditions before and after the 8.2 ka event (eg, the $\delta^{18} \mathrm{O}$ record of Greenland ice-cores, Figure 5), indications for the onset of warmer climatic conditions after 8200 cal. BP can be derived from chironomid-inferred temperatures (Heiri et al., 2003; Figure 5), from a stalagmite record in the Central Alps (Vollweiler et al., 2006) and from the elevation of treeline as inferred from dendrochronologically dated subfossil logs in the Austrian Alps (Nicolussi et al., 2005). In the Northern Alps, based on the evidence of a more temperate aquatic fauna at Bachalpsee, Lotter et al. (2006) suggest that warmer and/or longer summers could have favoured the expansion of Abies at $8400 \mathrm{cal}$. BP below timberline. A change towards a different climate regime around $8200 \mathrm{cal}$. BP has been suggested for Fennoscandia (Seppä and Birks, 2001; Seppä et al., 2005) by means of pollen-based summer temperature reconstructions and from $\delta^{18} \mathrm{O}$ records of lake carbonates. Seppä et al. (2005) suggested that the maritime climate mode that dominated until $8200 \mathrm{cal}$. BP in Fennoscandia was followed by a stable 'Holocene thermal maximum', which was characterized by higher annual temperatures and by markedly drier conditions. This enduring climatic change in Scandinavia may have been coupled to a shift towards oceanic and wetter conditions in Central Europe (Tinner and Lotter, 2006).

Despite the wealth of palaeobotanical data for change in vegetation composition at low elevation in Central Europe (Tinner and Lotter, 2001) and for timberline fluctuations in the Alps (eg, Tinner et al., 1996; Haas et al., 1998; Heiri et al., 2004), little is known concerning vegetation dynamics below timberline in response to abrupt climate changes. Results of modelling studies indicate that forests just below the treeline seem to be in a continuous state of change, involving dieback of trees in response to temperature decreases, after which more cold-adapted species can take advantage of reduced competition (Heiri et al., 2006). The time-resolution of the pollen and macrofossil records at Lac de Fully is probably not sufficiently high to reflect the reforestation succession in response to a centennial-scale temperature decrease. On the other hand, our results may indicate that vegetation near the modern timberline and below this elevation responded rapidly to the climate warming after c. 8200 cal. BP, allowing the observed expansions of Abies alba and Pinus cembra. It suggests also that moisture and/or local 


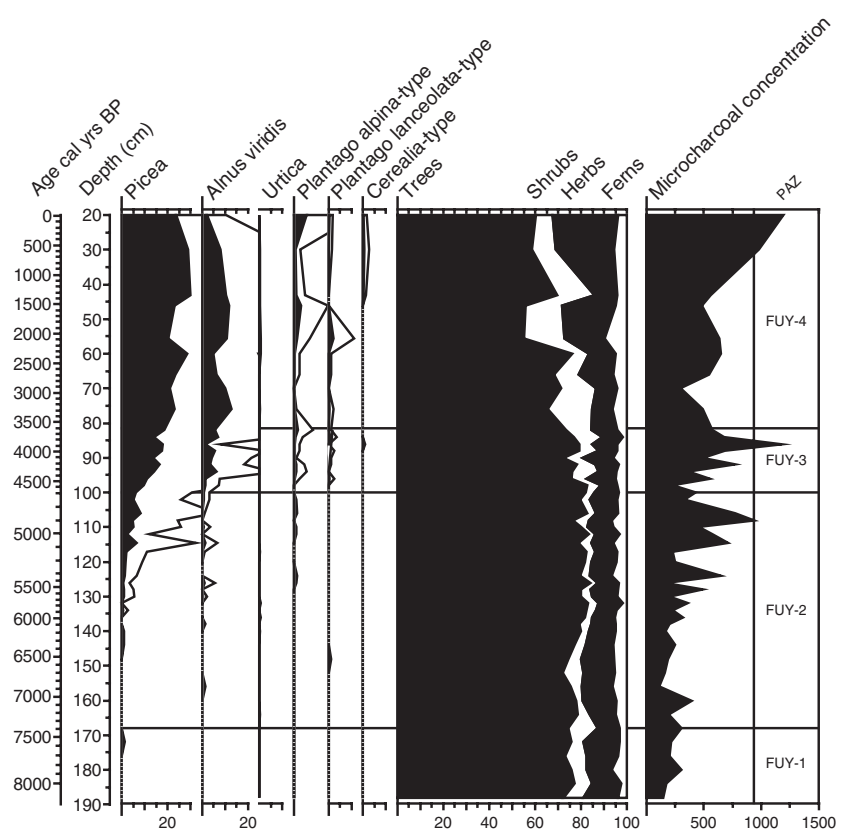

Figure 6 Selected pollen taxa and microcharcoal concentration (no. charcoal fragments $/ \mathrm{cm}^{3}$ ) for Lac de Fully

topography may play an important role in vegetation dynamics at timberlines in mountain regions.

\section{The demise of timberline forests as a result of human impact at Lac de Fully}

The first regular appearance of Cerealia t. pollen at lower elevation in the Valais is dated to 7000 cal. BP (Welten, 1982; van der Knaap and Ammann, 1997). However, unambiguous archaeological evidence for Neolithic land use was found in Sion and is dated to $c .7450$ cal. BP (Stöckli, 1995). First signs of human activities in the Lac de Fully pollen record are provided by pollen of cultural indicators that are present starting from $\sim 7300$ cal. BP (Urtica pollen), though land use became intensive only at around c. 4500 cal. BP (Figures 3 and 6). This finding is in agreement with other pollen records from the Valais (eg, Welten, 1982; Tinner et al., 1996), which suggest that agricultural activities intensified at the time of the Neolithic/Bronze Age transition at high elevation in the Valais region and elsewhere in the Alps (eg, Gobet et al., 2003; Lotter et al., 2006).

Pollen and macrofossils indicate that until $3500 \mathrm{cal}$. BP timberline forests were not disrupted by human impact. However, the forest at the timberline started to be opened around $4700 \mathrm{cal}$. BP (Figure 5), and the tree population decreased abruptly around 3500 cal BP at Lac de Fully. This pattern is typical for the Valais region, where the timberline lowered by about $300 \mathrm{~m}$ at $4700 \mathrm{cal}$. BP and was below $2100 \mathrm{~m}$ at c. 4000 cal. BP (Tinner and Theurillat, 2003). Palaeoecological and modelling evidence (Heiri et al., 2006) suggest that human impact was the primary cause of this timberline collapse. In contrast, treeline remained more or less stable, and it decreased by about only $100 \mathrm{~m}$ after $4700 \mathrm{cal}$. BP (Tinner and Theurillat, 2003). At Lac de Fully Picea, a subalpine tree, was more abundant after $4500 \mathrm{cal}$. BP than before, which is in agreement with other findings in the Valais (eg, Tinner et al., 1996). Spruce forests were probably placed at altitudes $<2000 \mathrm{~m}$ a.s.l., and it has been hypothesized that spruce was able to expand in response either to climatic change or to human impact (eg, Markgraf, 1970; Heiri et al., 2006).

Based on the pollen record, three distinct phases of human impact were distinguished. Between 3700-2600 cal. BP treeline was below Lac Supérieur de Fully, A. viridis expanded and grazing indicators (eg, $P$. alpina) were reduced. This might indicate a lessening of human impact and a reoccupation of abandoned areas by $A$. viridis that was later followed by Picea. However, it has been also hypothesized that the widespread expansion of $A$. viridis in the Valais was a consequence of land-use change and increased fire frequencies (cf. Welten, 1982; Tinner et al., 1996; Gobet et al., 2003). In agreement, microcharcoal values increased towards the top of this zone, indicating increasing regional fire activity (Figure 6). A second and clearer phase of human impact is indicated by higher percentages of $P$. alpina, P. lanceolata and Urtica pollen from c. 2000 to $1500 \mathrm{cal}$. BP. Also the higher abundance of Botrychium spores suggests more open ground near the lake (Figure 3). In addition, an opening of the spruce forest at lower elevation may be inferred from the decrease of Picea pollen and the increase of Vaccinium and $A$. viridis pollen. The last human-impact phase (younger than $1500 \mathrm{cal}$. BP) is characterized by Cerealia and Humulus/Cannabis pollen, which attest to the expansion of agriculture at lower altitudes. Timberline during this phase was further decreased, as can be inferred from lower A. viridis, Picea, Abies and $P$. cembra and increasing amounts of herb pollen. The increase of microscopic charcoal towards the top of the sequence (Figure 6) probably indicates that forest disruptions were partly caused by fire.

\section{Conclusions}

Pollen, stomata and plant-macrofossil analyses at Lac Supérieur de Fully (2135 $\mathrm{m}$ a.s.1.) indicate that the lake was located below the timberline from c. 9200 to $3500 \mathrm{cal}$. BP and that after, at latest, 4700 cal. BP vegetation around Lac Supérieur de Fully primarily responded to human impact. Maximum forest cover occurred after 8200 cal. BP, when P. cembra, Larix and Abies forests expanded on the south-exposed highland plateau or below. In comparison with other records in the Central Alps, at Lac Supérieur de Fully initial afforestation was delayed by several millennia. It is suggested that this change in vegetation was a response to the onset of a different climate mode, which began after c. $8200 \mathrm{cal}$. BP and involved less frequent droughts and spring frosts than during the early Holocene (Tinner and Lotter, 2001; Finsinger et al., 2006). Possibly local factors such as the position on a south-facing and the kettle-shaped highland plateau played a role by inhibiting, because of increased drought stress, the establishment of trees until 8200 cal. BP at Lac de Fully. It is noticeable that the late early-Holocene afforestation at Lac Supérieur de Fully was only recognized because of earlier studies in nearby regions. Thus, a network of well-studied and well-dated sites is important for studying spatial patterns of population expansion and noticing local climatic effects.

\section{Acknowledgements}

We wish to thank Philippe Curdy, Oliver Heiri and Lukas Zimmermann for discussions, Martin Schmidthalter for dendro-dating, Florencia Oberli for preparing the pollen samples and Herb Wright $\mathrm{Jr}$ for linguistic improvements. Financial support from the Musée Cantonal d'Histoire Naturelle (Sion, Valais; WF) is greatly acknowledged. We are further indebted to Hilary Birks and an anonymous reviewer for fruitful comments. This is Netherlands Research School of Sedimentary Geology no. 2007.06.04.

\section{References}

Alley, R.B. and Àgustdòttir, A.M. 2005: The 8k event: cause and consequences of a major Holocene abrupt climate change. Quaternary Science Reviews 24, 1123-49. 
Alley, R.B., Mayewski, P.A., Sowers, T., Stuiver, M., Taylor, K.C. and Clark, P.U. 1997: Holocene climatic instability: a prominent, widespread event 8200 yr ago. Geology 25, 483-86.

Autio, J. and Hicks, S. 2004: Annual variations in pollen deposition and meteorological conditions on the fell Aakenustunturi in northern Finland: potential for using fossil pollen as a climate proxy. Grana 43, 31-47.

Behre, K.-E. 1981: The interpretation of anthropogenic indicators in pollen diagrams. Pollen et Spores 23, 225-45.

Bennett, K.D. 1996: Determination of the number of zones in a biostratigraphical sequence. New Phytologist 132, 155-70.

Birks, H.H. and Birks, H.J.B. 2000: Future uses of pollen analysis must include plant macrofossils. Journal of Biogeography 27, 31-35. Birks, H.J.B. and Gordon, A.D. 1985: Numerical methods in Quaternary pollen analysis. Academic Press.

Burga, C.A. and Perret, R. 1998: Vegetation und Klima der Schweiz seit dem Jüngeren Eiszeitalter. Ott Verlag.

Came, R.E., Oppo, D.W. and McManus, J.F. 2007: Amplitude and timing of temperature and salinity variability in the subpolar North Atlantic over the past 10 k.y. Geology 35, 315-18. doi: 10.1130/G23455A.1.

Carnelli, A.L., Theurillat, J.-P., Thinon, M., Vadi, G. and Talon, B. 2004: Past uppermost tree limit in the Central European Alps (Switzerland) based on soil and soil charcoal. The Holocene 14, 393-405. Carrara, P.E., Trimble, D.A. and Rubin, M. 1991: Holocene treeline fluctuations in the northern San-Juan Mountains, Colorado, USA, as indicated by radiocarbon-dated conifer wood. Arctic and Alpine Research 23, 233-46.

Finsinger, W. and Tinner, W. 2005: Minimum count sums for charcoal-concentration estimates in pollen slides: reliability and potential errors. The Holocene 15, 293-97.

Finsinger, W., Tinner, W., van der Knaap, W.O. and Ammann, B. 2006: The expansion of hazel (Corylus avellana L.) in the southern Alps: a key for understanding its early Holocene history in Europe? Quaternary Science Reviews 25, 612-31.

Gobet, E., Tinner, W., Hochuli, P.A., van Leeuwen, J.F.N. and Ammann, B. 2003: Middle to Late Holocene vegetation history of the Upper Engadine (Swiss Alps): the role of man and fire. Vegetation History and Archaeobotany 12, 143-63.

Guiot, J., Harrison, S. and Prentice, I.C. 1993: Reconstruction of Holocene precipitation patterns in Europe using pollen and lake-level data. Quaternary Research 40, 139-49.

Haas, J.N., Richoz, I., Tinner, W. and Wick, L. 1998: Synchronous Holocene climatic oscillations recorded on the Swiss Plateau and at timberline in the Alps. The Holocene 8, 301-309.

Heiri, C., Bugmann, H., Tinner, W., Heiri, O. and Lischke, H. 2006: A model-based reconstruction of Holocene treeline dynamics in the Central Swiss Alps. Journal of Ecology 94, 206-16. doi: 10.1111/j.1365-2745.2005.01072.x.

Heiri, O., Lotter, A.F., Hausmann, S. and Kienast, F. 2003: A chironomid-based Holocene summer air temperature reconstruction from the Swiss Alps. The Holocene 13, 477-84.

Heiri, O., Tinner, W. and Lotter, A.F. 2004: Evidence for cooler European summers during periods of changing melt-water flux to the North Atlantic. Proceedings of the National Academy of Sciences of the United States of America 101, 15 285-88.

Kaltenrieder, P., Tinner, W. and Ammann, B. 2005: Long-term vegetation history at timberline in the Swiss Alps (Alpe d'Essertse, VS). Botanica Helvetica 115, 137-54.

Körner, C. 1999: Alpine plant life. Springer.

Körner, C. and Hoch, G. 2006: A test on treeline theory on a montane permafrost island. Arctic, Antarctic, and Alpine Research 38, 113-19. Körner, C. and Paulsen, J. 2004: A world-wide study of high altitude treeline temperatures. Journal of Biogeography 31, 713-32.

Kullman, L. 1995: Holocene tree-limit and climate history from the Scandes-Mountains, Sweden. Ecology 76, 2490-502.

2002: Rapid recent range-margin rise of tree and shrub species in the Swedish Scandes. Journal of Ecology 90, 68-77.

Kutzbach, J.E. and Webb, T., III 1993: Conceptual basis for understanding late-Quaternary climates. In Wright, H.E.J., Kutzbach, J.E., Webb, T., III, Ruddiman, W.F., Street-Perrott, F.A. and Bartlein, P.J., editors, Global climates since the Last Glacial Maximum. University of Minnesota Press, 5-11.

Landolt, E. 1992: Unsere Alpenflora. Gustav Fisher.
Lang, G. and Tobolski, K. 1985: Hobschensee - Late-Glacial and Holocene environment of a lake near the timberline. In Lang G., editor Swiss lake and mire environments during the last 15,000 years. Dissertationes Botanicae. J. Cramer, 209-28.

Lotter, A.F., Heiri, O., Hofmann, W., van der Knaap, W.O., van Leeuwen, J.F.N., Walker, I.R. and Wick, L. 2006: Holocene timberline dynamics at Bachalpsee, a lake at $2265 \mathrm{~m}$ a.s.l. in the northern Swiss Alps. Vegetation History and Archaeobotany 15, 295-307.

Markgraf, V. 1969: Moorkundliche und vegetationsgeschichtliche Untersuchungen an einem Moorsee and der Waldgrenze im Wallis. Botanische Jahrbücher 89, 1-63.

1970: Palaeohistory of the Spruce in Switzerland. Nature 228, $249-51$.

Menzel, A. and Fabian, P. 1999: Growing season extended in Europe. Nature 397, 659.

Moore, P.D., Webb, J.A. and Collinson, M.E. 1991: Pollen analysis. Blackwell Science Ltd.

Nesje, A., Dahl, S.O. and Bakke, J. 2004: Were abrupt Lateglacial and early-Holocene climatic changes in northwest Europe linked to freshwater outbursts to the North Atlantic and Arctic Oceans? The Holocene 14, 299-310.

Nesje, A., Bjune, A.E., Bakke, J., Dahl, S.O., Lie, O. and Birks, H.J.B. 2006: Holocene palaeoclimate reconstructions at Vanndalsvatnet, western Norway, with particular reference to the 8200 cal. yr BP event. The Holocene 16, 717-29. doi:10.1191/0959683606h1954rp.

Nicolussi, K., Kaufmann, M., Patzelt, G., van der Plicht, J. and Thurner, A. 2005: Holocene tree-line variability in the Kauner Valley, Central Eastern Alps, indicated by dendrochronological analysis of living trees and subfossil logs. Vegetation History and Archaeobotany 14, 221-34.

Parmesan, C. 2006: Ecological and evolutionary responses to recent climate change. Annual Review of Ecology, Evolution, and Systematics 37, 637-69, doi: 10.1146/annurev.ecolsys.37.091305.110100.

Rasmussen, S.O., Andersen, K.K., Svensson, A.M., Steffensen, J.P., Vinther, B.M., Clausen, H.B., Siggaard-Andersen, M.-L., Johnsen, S.J., Larsen, L.B., Dahl-Jensen, D., Bigler, M., Röthlisberger, R., Fischer, H., Goto-Azuma, K., Hansson, M.E. and Ruth, U. 2006: A new Greenland ice core chronology for the last glacial termination. Journal of Geophysical Research 111, D06102, doi:10.1029/2005JD006079.

Reille, M. 1992: Pollen et spores d'Europe et d'Afrique du nord. Laboratoire de Botanique Historique et Palynologie.

_ 1995: Pollen et spores d'Europe et d'Afrique du Nord supplement 1. Laboratoire de Botanique Historique et Palynologie.

Reimer, P.J., Baillie, M.G.L., Bard, E., Bayliss, A., Beck, J., Bertrand, C.J.H., Blackwell, P.G., Buck, C.E., Burr, G.S., Cutler, K.B., Damon, P.E., Edwards, R.L., Fairbanks, R.G., Friedrich, M., Guilderson, T.P., Hogg, A.G., Hughen, K.A., Kromer, B., McCormac, G., Manning, S., Ramsey, C.B., Reimer, R.W., Remmele, S., Southon, J.R., Stuiver, M., Talamo, S., Taylor, F.W., van der Plicht, J. and Weyhenmeyer, C.E. 2004: IntCal04 terrestrial radiocarbon age calibration, 0-26 cal kyr BP. Radiocarbon 46, 1029-58. Rohling, E.J. and Pälike, H. 2005: Centennial-scale climate cooling with a sudden cold event around 8,200 years ago. Nature 434, 975-79. Seppä, H. and Birks, H.J.B. 2001: July mean temperature and annual precipitation trends during the Holocene in the Fennoscandian treeline area: pollen-based climate reconstructions. The Holocene 11, $527-39$.

Seppä, H., Hammarlund, D. and Antonsson, K. 2005: Low-frequency and high-frequency changes in temperature and effective humidity during the Holocene in south-central Sweden: implications for atmospheric and oceanic forcings of climate. Climate Dynamics 25, 285-97.

Steiger, P. 1995: Wälder der Schweiz. Ott Verlag.

Stöckli, W.E. 1995: Geschichte des Neolithikums in der Schweiz. In Stöckli, W.E., Niffeler, U. And Gross-Klee, E., editors, Die Schweiz vom Paläolithikum bis zum frühen Mittelalter - Neolithikum. Schweizerische Gesellschaft für Ur- und Frühgeschichte, 19-52. Stockmarr, J. 1971: Tablets with spores used in absolute pollen analysis. Pollen et Spores 13, 615-21.

Tinner, W. and Hu, F.S. 2003: Size parameters, size-class distribution and area-number relationship of microscopic charcoal: relevance for fire reconstruction. The Holocene 13, 499-505. 
Tinner, W. and Kaltenrieder, P. 2005: Rapid responses of highmountain vegetation to early Holocene environmental changes in the Swiss Alps. Journal of Ecology 93, 936-47.

Tinner, W. and Lotter, A.F. 2001: Central European vegetation response to abrupt climate change at $8.2 \mathrm{ka}$. Geology 29, 551-54.

2006: Holocene expansions of Fagus silvatica and Abies alba in Central Europe: where are we after eight decades of debate? Quaternary Science Reviews 25, 526-49.

Tinner, W. and Theurillat, J.-P. 2003: Uppermost limit, extent, and fluctuations of the timberline and treeline ecotone in the Swiss Central Alps during the past 11,500 years. Arctic, Antarctic, and Alpine Research 35, 158-69.

Tinner, W., Ammann, B. and Germann, P. 1996: Treeline fluctuations recorded for 12,500 years by soil profiles, pollen, and plant macrofossils in the Central Swiss Alps. Arctic and Alpine Research 28, 131-47.

Trautmann, W. 1953: Zur Unterscheidung fossiler Spaltöffnungen der mitteleuropäischen Coniferen. Flora 140, 523-33.

van der Knaap, W.O. and Ammann, B. 1997: Depth-age relationships of 25 well-dated Swiss Holocene pollen sequences archived in the Alpine Palynological Data-Base. Revue de Paléobiologie, Genève 16, 433-80.

Vollweiler, N., Scholz, D., Mühlinghaus, C., Mangini, A. and Spötl, C. 2006: A precisely dated climate record for the last $9 \mathrm{kyr}$ from three high alpine stalagmites, Spannagel Cave, Austria. Geophysical Research Letters 33, L20703, doi: 10.1029/2006GL027662.

von Grafenstein, U., Erlenkeuser, H., Müller, J., Jouzel, J. and Johnsen, S. 1998: The cold event 8200 years ago documented in oxygen isotope records of precipitation in Europe and Greenland. Climate Dynamics 14, 73-81.

Welten, M. 1982: Vegetationsgeschichtliche Untersuchungen in den westlichen Schweizer Alpen: Bern-Wallis. Denkschrift der Schweizerischen Naturforschenden Gesellschaft 95, 1-104.

Wick, L. and Tinner, W. 1997: Vegetation changes and timberline fluctuations in the Central Alps as indicators of Holocene climatic oscillations. Arctic and Alpine Research 29, 445-58.

Wohlfahrt, B., Skog, G., Possnert, G. and Holmquist, B. 1998 Pitfalls in the AMS radiocarbon-dating of terrestrial macrofossils. Journal of Quaternary Science 13, 137-45.

Zweifel, R., Zimmermann, L., Zeugin, F. and Newbery, D.M. 2006: Intra-annual radial growth and water relations of trees: implications towards a growth mechanism. Journal of Experimental Botany $57,1445-59$ 